\title{
PEMBELAJARAN MATEMATIKA BERBASIS INFORMATIKA
}

\author{
Khusnul Khotimah ${ }^{1}$ \\ ${ }^{1}$ Program Studi Pendidikan Matematika, STKIP Muhammadiyah Kotabumi \\ email:ima.ukhti@gmail.com
}

\begin{abstract}
Abstact
The Mathematic Teaching and learning based informatic system is learning system implementing computerization technology as a learning tool in the teaching and learning process. This teaching and learning process in which it combines conventional method with the application practice has been constructed on the basis of the implemented curriculum in a college. The use of media in a teaching and learning process like computer as a learning tool will make the teaching and learning process more effective because it will create an interesting teching and learning process as well as stimulate the students' creativity. In addition, the teaching and learning process not only as a tutorial qctivity but also it provides the implentation of the theories given. The Mathematic teaching and learning based informatic is done to know the comparison of problem solving in mathematic using Mathematic software application. The standardized process and the use of informatic are constructed based on the exsisting curriculum in order to control the quality of the learning proses and result.
\end{abstract}

Keywords: Mathematic teaching and learning, Mathematic based informatic

\section{A. PENDAHULUAN}

Pembelajaran merupakan proses interaksi peserta didik dengan pengajar dan sumber belajar pada suatu lingkungan belajar (UU RI No. 20/2003: Sisdiknas Bab I, Pasal 1, ayat 20). Berdasarkan undang-undang tersebut, dapat disimpulkan bahwa pembelajaran merupakan interaksi antara dosen dan mahasiswa dengan melibatkan sumber belajar. Dosen merupakan fasilitator sekaligus pembimbing yang harus mencip-takan suasana pembelajaran menjadi menarik serta kondusif.

Pemanfaatan teknologi informatika dalam pembelajaran matematika menjadikan terbentuknya sebuah pemahaman baru dalam dunia pendidikan. Pembelajaran yang selama ini masih dilakukan secara konvensional menggunakan alat peraga mulai beralih dengan mengkombinasikan unsur teknologi didalamnya. Kemudian hal in yang lebih dikenal dengan pembelajaran berbasis informatika. Penggunaan teknologi informatika dalam model pembelajaran matematika memiliki keunggulan dibandingkan dengan model pembelajaran konvensional meng-gunakan alat peraga. Teknologi informatika mampu menampilkan informasi secara lebih jelas, cepat, dan dapat memvisualisasikan suatu yang abstrak. Adanya kemudahan dalam proses pembelajaran dalam praktik secara langsung dengan dukungan teknologi memberikan kemudahan dan daya tarik positif dalam proses pembelajaran matematika. 


\section{B. PEMBELAJARAN MATEMATIKA}

Pembelajaran matematika menurut Suherman (Fitri et al., 2014) adalah suatu proses dimana siswa/mahasiswa secara aktif membangun pengetahuan matematika. Selanjutnya Uno (2010) berpendapat bahwa pembelajaran matematika merupakan suatu kegiatan dalam memahami arti, hubunganhubungan dan simbol-simbol yang kemudian diimplementasikan dalam situasi nyata. Belajar matematika berhubungan dengan bagaimana implementasinya untuk membuat suatu keputusan dalam penyelesaian/pemecahan masalah. Berdasarkan definisi di atas dapat disimpulkan bahwa pembelajaran matematika akan dapat dengan mudah difahami oleh mahasiswa jika mahasiswa mampu mempraktikkan/mengimplementasikan dengan pengalaman berdasarkan teori-teori atau materi-materi yang sebelumnya telah dipelajari. Untuk mengoptimalkan pencapaian dari tujuan pembelajaran maka peran dari seorang Dosen sangatlah penting agar proses pembelajaran matematika dapat lebih optimal lagi.

\section{PEMBELAJARAN MATEMATIKA} BERBASIS INFORMATIKA

Teknologi informatika sebagaimana diungkapkan oleh beberapa orang ahli antara lain menurut Elston (Budiana et al., 2015) "IT as the technology uses to managed information". IT merupakan teknologi yang digunakan untuk mengelola suatu informasi. Menurut William \& Sawyer (Husaini, 2014) 88 teknologi informasi merupakan teknologi yang memadukan komputer dengan jalur komunikasi kecepatan tinggi, yang berisi data, audio, dan video.

Menurut Martin ( Husaini, 2014), teknologi informasi tidak terbatas hanya pada teknologi komputer saja seperti software dan hardware yang digunakan dalam pengolahan dan penyimpanan informasi, melainkan termasuk didalamnya teknologi komunikasi untuk mendistribusi-kan informasi. Berdasarkan pendapat para ahli tersebut dapat disimpulkan teknologi informasi bukan hanya berupa alat yang terdiri dari hardware dan software yang digunakan sebagai alat bantu dalam memproses, manipulasi, dan pengelolaan informasi tetapi juga didalamnya teknologi komunikasi yang digunakan untuk menyebarkan informasi. Fungsi utama dalam pemanfatan teknologi harus memperhatikan unsur dari nilai kepraktisan, keefektifan dan efisiensi sebagai pondasi utama. Artinya apabila penggunaan teknologi ini nantinya menyulitkan dan menambah beban materi pembelajaran dan menjadikan waktu tidak dapat diprediksi maka penggunaan teknologi informasi tidak akan ada manfaatnya.

\section{PRINSIP-PRINSIP PEMBELAJARAN MATEMATIKA BERBASIS INFORMATIKA}

Prinsip umum pembelajaran matematika berbasis informatika, adalah sebagai berikut:

1. Efektif dan efisien 
Penggunaan teknologi informatika harus memperhatikan dari segi manfaat dari teknologi itu sendiri. Keterkaitan antara efektifitas dan efisiensi belajar, meliputi tersedianya fasilitas pendukung, kemudahan dalam penyajian dan pengajaran ilmu, serta keterjangkauan baik dalam segi waktu dan biaya.

2. Optimal dalam Pemanfaatan Dengan menggunakan teknologi informatika, pembelajaran akan memiliki nilai lebih daripada sebelum menggunakan teknologi. Nilai lebih dapat berupa keluasan cakupan, update/pembaharuan, dapat praktik secara langsung langsung, lebih modern dan luas.

3. Menarik

Penggunaan teknologi informatika menjadikan pembelajaran di kelas akan lebih menarik dan menumbuhkan keingintahuan yang lebih bagi dalam diri mahasiswa. Hal ini dikarenakan pembelajaran yang cenderung monoton sering menyebabkan pembelajaran menjadi sangat membosankan. Dengan melibatkan teknologi dalam pembelajaran, materi dapat disajikan dengan lebih menarik dan informatif.

4. Merangsang pola fikir kreativitas mahasiswa

Pembelajaran matematika berbasis informatika tentu saja bertujuan merangsang daya berfikrir kreatif mahasiswa yang maksimal dalam diri mahasiswa itu sendiri. Mahasiswa yang mempunyai kreatifitas tinggi tentunya akan mampu menyelesaikan permasalahan dengan cepat dan tanggap terhadap permasalahan yang muncul. Mahasiswa dapat mengetahui dan membandingkan bagaimana cara penyelesaian masalah dengan proses biasa (konvensional) dan dengan penyelesaian menggunakan aplikasi terapan.

Dengan prinsip umum pembelajaran matematika berbasis informatika, tujuan dari penggunaan teknologi informatika dalam pembelajaran menjadi sejalan dengan tujuan pendidikan yang akan dicapai. Penggunaan teknologi informatika bukan malah menjadi penghambat dalam proses pembelajaran namun justru akan memberi nilai tambah dan manfaat yang lebih dalam peningkayan mutu pembelajaran.

\section{E. Aplikasi Pembelajaran Matematika Berbasis Informatika}

Pada saat ini, pembelajaran matematika berbasis informatika di lingkungan perguruan tinggi merupakan hal yang sangat penting. Hal ini dikarenakan semakin meningkatnya kebutuhan informasi dan komunikasi dalam berbagai keperluan yang seiring dengan perkembangan dari ilmu pengetahuan dan teknologi (IPTEK) dan pembaharuan kurikulum perguruan tinggi. Teknologi informatika yang secara sederhana digambarkan dengan adanya perangkat 
komputer (hardware), aplikasi-aplikasi (software) dan jaringan internet (wifi) telah banyak dimanfaatkan untuk meningkatkan produktivitas pemahaman mahasiswa suatu perguruan tinggi.

Beberapa teknologi dalam pembelajaran antara lain:

1. Pembelajaran Berbasis Komputer

Pembelajaran berbasis komputer, yaitu penggunaan komputer sebagai alat bantu dalam dunia pendidikan dan pengajaran. Penggunaan komputer secara langsung dengan mahasiswa untuk menyampaikan isi pelajaran, memberikan latihan dan mengevaluasi kemajuan belajar mahasiswa. Materi pembelajaran biasanya disajikan dibuat dalam bentuk powerpoint atau CD pembelajaran interaktif. Pembelajaran berbasis komputer merupakan program pembelajaran yang digunakan dalam proses pembelajaran dengan menggunakan software komputer.

\section{E-Learning}

$E$-Learning adalah pembelajaran dengan menggunakan jaringan internet sebagai fasilitas pengantar materi sebagai bentuk interaksi. E-Learning disebut juga pembelajaran secara online. Pada pembelajaran model ini pembelajaran dapat disajikan dalam format: a) E-mail (Dosen dan mahasiswa berinteraksi dalam pembelajaran dengan menggunakan fasilitas surat elektronik; b) grup diskusi (Mailing List), proses pembelajaran bisa menggunakan fasilitas e-mail, facebook, twitter; dan lain-lain; c) Mengunduh bahan ajar dari internet (download), mahasiswa dapat mencari bahan ajar, literatur dan referensi melalui internet untuk menambah pengetahuan tentang pokok bahasan yang sedang dipelajari; d) Pembelajaran interaktif melalui web; e) Interactive Conferencing, berupa pembelajaran yang dilakukan langsung tatap muka namun dalam jarak yang jauh.

3. Pembelajaran berbasis web/blog Dalam hal ini sebagai seorang Dosen harus memiliki sebuah website/blog yang nantinya berisi materi-materi kuliah sesuai dengan SAP yang telah dibuat. Dosen harus mempunyai blog sendiri untuk matakuliah yang diampunya, sehingga Dosen dapat berkomunikasi tentang materi dengan mahasiswa di dunia maya, dengan demikian akan tercipta kelas dunia maya (virtual class room). Hal ini akan dapat memotivasi keaktifan dan tentnya menambah wawasan pengetahuan mahasiswa.

\section{Perpustakaan online}

Sumber belajar utama dan pokok bagi mahasiswa adalah buku-buku dengan referensi yang lengkap. Buku-buku tersebut biasanya tersedia di perpustakaan suatu perguruan tinggi. Semakin banyaknya koleksi buku pada perpustakaan dan semakin banyaknya mahasiswa yang membutuhkan referen-si 
dari buku di perpustakaan, maka dibutuhkan suatu manajemen pengelolaan perpustakaan yang baik. Salah satu strategi pelayanan perpustakaan berbasis komputer adalah akses perpustakaan secara online. Perpustakaan online merupakan fasilitas perpustakaan dalam dunia digital yang terhubung melalui jaringan internet secara global dan luas yang memungkinkan seseorang baik itu Dosen dan mahasiswa dapat mencari informasi dan mengakses bahan ajar dari segala sumber ilmu pengetahuan dengan cara yang mudah tentunya tanpa adanya batasan waktu dan tempat.

\section{F. Dampak Positif dan Negatif}

\section{Pembelajaran Matematika Berbasis}

\section{Informatika}

Keuntungan yang memberikan dampak positif dalam pembelajaran matematika berbasis teknologi informatika antara lain adalah:

1. Mahasiswa menjadi lebih mudah dalam belajar, karena kebanyakan mahasiswa lebih suka praktek langsung dibandingkan teori

2. Dosen menjadi lebih mudah menyampaikan materi dengan membuat presentasi-presentasi dan multimedia

3. Penugasan dari materi tidak harus bertatap muka, seperti contoh jika dosen berhalangan hadir tetap dapat memberi tugas atau materi melalui blog atau e-mail

4. Teori yang disampaikan oleh dosen akan mudah diserap mahasiswa karena langsung dapat diujicobakan pada aplikasi yang digunakan.

Ketika pembelajaran matematika berbasis teknologi informatika memiliki dampak positif, tentunya juga memiliki kekurangan, diantaranya:

1. Model pembelajaran matematika berbasis teknologi informasi hanya bisa dilaksanakan jika fasilitas sarana tersedia dan terorganisir dengan baik, sedangkan jika tanpa dukungan fasilitas tersebut sangat mustahil pembelajaran ini dapat diterapkan.

2. Setiap mahasiswa harus mendapat fasilitas yang sama dalam pembelajaran, dalam implementasinya setiap mahasiswa harus memakai satu komputer yang memadai dan dalam kondisi baik. Ketidakseimbangan antara jumlah fasilitas dan mahasiswa tentu saja dapat menghambat proses pembelajaran.

3. Ketidakmenarikan materi pembelajaran dapat menyebabkan mahasiswa kurang antuasias, kurang respon dalam memahami materi, adakalanya dalam pembelajaran berbasis informatika ini perlu juga penggunaan metode pengajaran yang tepat.

4. Akses internet yang tidak dibatasi atau tidak dikontrol, hal ini terkadang 
dimanfaatkan mahasiswa bukan untuk keperluan belajar, sebagai contoh ada mahasiswa yang membuka situs youtube untuk menonton video, membuka aplikasi game sedangkan pada saat itu proses pembelajaran sedang berlangsung.

\section{G. Kelebihan dan Kekurangan}

\section{Pembelajaran Matematika Berbasis}

\section{Infomatika}

Adapun kelebihan dari penggunaan model pembelajaran matematika berbasis teknologi infomatika adalah sebagai berikut.

1. Sistem pembelajaran menjadi lebih inovatif dan interaktif. Dosen dituntut untuk dapat membuat media yang inovatif dan informatif.

2. Menimbulkan nilai positif, kegairahan belajar, rasa senang dan motivasi mahasiswa selama proses belajarmengajar, sehingga pemahaman mahasiswa menjadi meningkat.

3. Penggunaan teknologi informatika mampu menyajikan materi yang bersifat abstrak untuk di visualisasikan.

4. Kemudahan dalam hal proses penyimpanan dan pencarian kembali hasil pembelajaran

Kekurangan dari pembelajaran matematika berbasis teknologi informatika:

1. Permasalahan dalam pengaturan dan pengoperasian dari fasilitas yang tersedia

2. Terlalu mahal untuk dimiliki
3. Kesulitan untuk Dosen dengan pengalaman yang sangat minim dalam penggunaan alat dan aplikasi sehingga diperlukan sebuah pelatihan penggunaannya.

4. Sering kali terjadi penyalahgunaan dan menyimpangan pemanfaatan teknologi

\section{H. Komponen Pendukung Pembelajaran Matematika Berbasis Informatika}

Dalam model pembelajaran matematika berbasis teknologi informatika dibutuhkan komponen yang terdiri dari perangkat keras (hardware) dan perangkat lunak (software). Beberapa perangkat lunak yang dapat digunakan untuk model pembelajaran teknologi informatika meliputi: unit PC, scanner, speaker, microfon, CD/DVD Drive, kamera digital, dan sebagainya. Sedangkan Software yang digunakan sebagai media pembelajaran berbasis teknologi informatika sangat beragam, mulai dari software yang umum digunakan sampai software yang khusus untuk aplikasi matematika.

Beberapa software yang dapat digunakan dalam model pembelajaran matematika berbasis teknologi informatika meliputi:

1. Software matematika (SPSS, Geogebra, Matlab, WinQSB, dll) digunakan untuk perhitungan matematika;

2. Paket Office (Word, Excel, Power Point) dapat digunakan untuk membuat tampilan berupa teks, gambar, tabel, grafik, simulasi, slide presentasi interaktif. 
3. Software desain grafis (Adobe mudah dipahami dan dapat langsung Photoshop/Correl Draw/MS Publisher/ photoscape) dapat digunakan untuk mengolah grafis/gambar;

4. Software pengolah video (Camtasia Studio, MS Movie Maker): dapat digunakan untuk mengolah dan pengambilan gambar/capturing);

5. Software Animasi (Macromedia/Adobe Flash/I-Spring) dapat digunakan untuk membuat suatu animasi gambar dan teks.

6. Software Nero merupakan salah satu software pembakar CD (Compact Disk) ; dan masih banyak lagi software lainnya.

\section{SIMPULAN}

Pembelajaran matematika berbasis teknologi informatika merupakan model pembelajaran yang telah disesuaikan berdasarkan kurikulum perguruan tinggi. Teknologi informatika dapat digunakan untuk membantu dosen dalam menyampai- kan materi pembelajaran dengan lebih menarik, dipraktikkan menggunakan aplikasi. Model pembelajaran ini mampu menyajikan media yang menarik dan secara efektif dan efisien dapat merangsang daya kreativitas mahasiswa. Praktik secara langsung dari teori yang disampaikan dalam pembelajaran menjadi salah satu model pembelajaran yang digunakan. Salah satu contoh penggunaannya dalam pembelajaran antara lain sebagai tutorial dan aplikasi terapan.

Beberapa software yang sering digunakan antara lain, Software matematika, paket office, software desain grafis, software pengolah video, software animasi, dan Nero. Pemanfaatan teknologi informasi dalam pembelajaran saat ini sangat perlu dilakukan, hal ini untuk menjadi solusi dari permasalahan peningkatan efektifitas dan efisiensi dibidang pendidikan. Standarisasi dan pemanfaatan teknologi informatika didasarkan pada kurikulum yang telah dibuat untuk menjamin mutu, proses, dan hasil.

\section{DAFTAR PUSTAKA}

Budiana, H.R., dkk. 2015. Pemanfaatan Teknologi Informasi dan Komunikasi dalam Pembelajaran bagi Para Guru SMPN 2 Kawali Desa Citeureup Kabupaten Ciamis. Dalam Jurnal Aplikasi Ipteks untuk Masyarakat, Vol. 4, (1): 59-62.

Departemen Pendidikan Nasional, 2003. Undang-Undang Nomor 20 Tahun 2003, Tentang

Sistem Pendidikan Nasional, Jakarta: Depdiknas. 
Fitri, Rahma, dkk. 2014. Penerapan Strategi The Firing Line pada Pembelajaran Matematika Siswa Kelas XI IPS SMA Negeri 1 Batipuh. Dalam Jurnal Pendidikan Matematika: Part 2, Vol. 3 (1): $18-26$

Husaini, M. Pemanfaatan Teknologi Informasi dalam Bidang Pendidikan. Dalam Jurnal Mikrotik. Vol. 2 (1): $1-8$

Uno, Hamzah B. 2010. Model Pembelajaran Menciptakan Proses Belajar Mengajar yang Kreatif dan Efektif. Jakarta: Bumi Aksara 
Pembelajaran Matematika Berbasis Informatika (Khusnul Khotimah) 